\title{
Perilaku Merokok Pada Remaja
}

\author{
Widya Rahmawati, Muhammad Ali Sodik \\ Institut Ilmu Kesehatan STRADA INDONESIA \\ rahmawatiwidya82@gmail.com, alisodik2012@gmail.com
}

\begin{abstract}
Abstrak
Perilaku merokok adalah aktivitas menghisap atau menghirup asap rokok dengan menggunakan pipa atau rokok yang dilakukan secara menetap dan terbentuk melalui empat tahap, yaitu: tahap preparation, initiation, becoming a smoker, dan maintenance of smoking (Maman, 2009).

Merokok merupakan salah satu masalah yang sulit di pecahkan. Hal ini menjadi sulit, karena berkaitan dengan banyak faktor yang saling memicu, sehingga seolah-olah sudah menjadi lingkaran setan. Terlebih diketahui bahwa sebagian besar adalah remaja, kebiasaan merokok bagi para remaja bermula karena kurangnya informasi dan kesalah pahaman informasi, termakan iklan atau terbujuk rayuan teman. Banyak yang beranggapan bahwa merokok dapat menghilangkan stress. Padahal hal tersebut merupakan sebagian dari efek dari nikotin yang sifatnya memberikan rasa tenang sesaat. Di tinjau dari segi kesehatan, merokok harus di hentikan karena menyebabkan kanker di penyumbatan pembuluh darah yang mengakibatkan kematian, oleh karena itu merokok harus di hentikan sebagai usaha pencegahan sedini mungkin. Sehingga perlu adanya pencegahan dini yang dimulai dari pihak sekolah dan orang tua.
\end{abstract}

\section{Kata kunci : merokok, rokok, nikotin, remaja}

\section{Latar Belakang}

Pada zaman modern ini, rokok bukanlah benda asing lagi. Baik mereka yang hidup di kota maupun di desa pada umumnya sudah mengenal benda yang bernama rokok ini. Bahkan oleh sebagian orang, rokok sudah menjadi kebutuhan hidup yang tidak bisa ditinggalkan begi tu saja dalam kehidupan sehari hari.Tanpa alasan yang jelas, seseorang akan merokok baik setelah makan, saat minum kopi atau teh, bahkan sambil bekerjapun sering diselingi dengan merokok. Rokok sudah menjadi kebudayaan manusia (Jaya, 2009).

Perilaku merokok adalah aktivitas menghisap atau menghirup asap rokok dengan menggunakan pipa atau rokok yang dilakukan secara menetap dan terbentuk melalui empat tahap, yaitu: tahap preparation, initiation, becoming a smoker, dan maintenance of smoking (Maman, 2009) Jumlah konsumsi rokok di Indonesia menurut The Tobaco Atlas 2002,menempati pososi kelima di dunia yaitu sebesar 215 miliar batang. Mengikuti China sebanyak 1,634 triliun batang, Amerika Serikat sebanyak 451 miliar batang, Jepang sebanyak 328 miliar batang, dan Rusia sebanyak 258 miliar batang. Badan kesehatan dunia WHO menyebutkan bahwa di Amerika, sekitar 346 ribu orang meninggal tiap tahun dikarenakan rokok. Dan tidak kurang dari $90 \%$ dari 660 orang yang terkena penyakit kanker di salah satu rumah sakit sanghai Cina adalah disebabkan rokok (Jaya, 2009).

Timbulnya kebiasan merokok ini biasanya diawali dari melihat orang sekitarnya 
merokok. Banyak anak- anak menganggap bahwa dengan merokok akan menjadi lebih dewasa. Ada pula yang merasa dengan

\section{Kasus / Masalah}

Apa faktor yang mempengaruhi kebiasaan merokok?

Bagaimana dampak dari perilaku merokok?

\section{Tinjauan Pustaka}

Rokok adalah salah satu produk tembakau yang dimaksudkan untuk dibakar dan dihisap dan / atau dihirup asapnya, termasuk rokok kretek, rokok putih, cerutu atau bentuk lainnya yang dihasilkan dari tanaman nicotiana tabacum, nicotiana rustica,dan spesies lainnya atau sintetisnya yang asapnya mengandung nikotin dan tara dengan atau tanpa bahan tambahan (PP No. 109 tahun 2012).

Rokok adalah silinder dari kertas berukuran panjang sekitar 70-120 mm (bervariasi tergantung negara) dengan diameter sekitar $10 \mathrm{~mm}$ yang berisi daundaun tembakau yang telah dicacah. Rokok dibakar pada salah satu ujungnya dan dibiarkan membara agar asapnya dapat

Faktor-faktor yang mempengaruhi perilaku merokok Menurut Juniarti(1991) dalam Mu'tadin (2002) dalam Poltekkes Depkes Jakarta 1 (2012), faktor yang mempengaruhi kebiasaan merokok adalah sebagai berikut :

a. Pengaruh Orang Tua Salah satu temuan remaja perokok adalah bahwa anakanak muda yang berasal dari rumahtangga yang tidak bahagia, dimana orang tua tidak begitu memperhatikan anak-anaknya dan memberikan hukuman yang keras.

b. Pengaruh teman, semakin banyak remaja yang merokok maka semakin besar kemungkinan teman-temanya adalah perokok dan demekian sebaliknya. Dari fakta tersebut ada dua kemungkinan yang terjadi. Pertama, merokok akan menimbulkan ketenangan, terlepas dari rasa takut dan gelisah (Aqib, 2011).

dihirup melalui mulut pada ujung lainnya (Aula, 2010).

Perilaku merokok didefinisikan sebagai aktivitas subjek yang berhubungan dengan perilaku merokoknya, yang diukur melalui intensitas merokok, waktu merokok, dan fungsi merokok dalam kehidupan sehari- hari (Komalasari \& Helmi, 2000). Sementara Leventhal \& Cleary (1980) menyatakan bahwa perilaku merokok terbentuk melalui empat tahap, yaitu:tahap preparation, initiation, becoming a smoker, dan maintenance of smoking. Berdasarkan uraian di atas dapat disimpulkan bahwa perilaku merokok adalah aktivitas menghisap atau menghirup asap rokok dengan menggunakan pipa atau rokok yang dilakukan secara menetap dan terbentuk melalui empat tahap, yaitu: tahap preparation, initiation, becoming a smoker, dan maintenance of smoking. (Maman, 2009).

remaja tadi terpengaruh oleh teman-temanya, atau bahkan temen-temen remaja tersebut dipengaruhi oleh remaja tersebut.

c. Faktor kepribaian Orang coba untuk merokok karena alasan ingin tahu tau ingin melepaskan diri dari rasa sakit fisik atau jiwa dan membebaskan diri dari kebosanan.

d. Pengaruh iklan Melihat iklan dimedia massa dan elektronik ysng menampilkan gambaran bahwa perokok adalah lambang kejantanan atau glamour. Membuat remaja sering kali terpicu untuk meniru perilaku perilaku seperti yang ada di dalam iklan tersebut.

\section{Pembahasan}

Merokok merupakan salah satu masalah yang sulit di pecahkan. Apalagi sudah menjadi 
masalah nasional, dan bahkan internasional. Hal ini menjadi sulit, karena berkaitan dengan banyak faktor yang saling memicu, sehingga seolah-olah sudah menjadi lingkaran setan. Di tinjau dari segi kesehatan, merokok harus di hentikan karena menyebabkan kanker di penyumbatan pembuluh darah yang mengakibatkan kematian, oleh karena itu merokok harus di hentikan sebagai usaha pencegahan sedini mungkin. Terlebih diketahui bahwa sebagian besar adalah remaja sehingga perlu adanya pencegahan dini yang dimulai dari pihak sekolah dan orang tua.

Para perokok merasakan nikmatnya merokok begitu nyata, sampai dirasa memberikan rasa menyenangkan dan menyegarkan sehingga setiap harinya harus menyisihkan uang untuk merokok. Kelompok lain, khususnya remaja pria, mereka menganggap merokok adalah merupakan ciri kejantanan yang membanggakan, sehingga mereka yang tidak merokok malah justru diejek. Padahal mereka sadar bahwa merokok dapat membahayakan kesehatan bahkan menimbulkan banyak penyakit serius. Banyak terdapat kandungankandungan yang berbahaya di dalam rokok sehingga menimbulkan dampak buruk bagi kesehatan.

\section{Dampak Perilaku Merokok}

- Bagi diri sendiri

1. Merokok lebih banyak mendatangkan kerugian dibandingkan keuntungan bagi tubuh.

2. Menimbulkan sugesti kepada diri kita, bahwa jika kita tidak merokok mulut tidak enak dan asam.

3. Rasa ingin tahu, semangat untuk belajar, dan berbagai hal positif yang ada pada diri kita hilang ketika kita menjadi seorang perokok.

- Bagi orang lain
1. Ketika kita sedang merokok, asap rokok kita dapat mengganggu orang lain dan juga menyebabkan polusi udara.

2. Menyebabkan seseorang yang dekat dengan kita menjadi perokok pasif.

3. Jika membuang puntung rokok sembarangan tanpa mematikan terlebih dahulu dapat menyebabkan kebakaran.

\section{Menyebabakan menipisnya lapisan ozon.}

Faktor-faktor penyebab remaja merokok

a. Faktor sosial, Faktor terbesar dari kebiasaan merokok dipengaruhi oleh faktor sosial atau lingkungan, dimana karakter seseorang banyak dibentuk oleh lingkungan sekitar,baik keluarga, tetangga, ataupun teman pergaulannya. Bersosialisasi merupakan cara utama pada anak-anak dan remaja untuk mencari jati diri mereka.Dengan melihat apa yang dilakukan orang lain dan kadang kala mencoba untuk meniru apa yang dilakukan orang lain.Hal itu merupakan suatu proses yang terjadi pada remaja untuk mencari jati diri dan belajar menjalani hidup bersosial.Namun sangat disayangkan, tidak hanya kebiasaankebiasaan yang baik saja yang ditiru melainkan juga kebiasaan kebiasaan buruk, termasuk kebiasaan merokok.

b. Kebutuhan menghisap dan mengunyah Setiap orang memiliki kebutuhan untuk mengisap dan mengunyah. Kebutuhan ini mulai ada sejak kita lahir yaitu kebutuhan untuk minum susu, dan secara berangsurangsur berkurang dan hilang, tetapi pada beberapa orang masih ada sampai dewasa. Beberapa orang menggunakan rokok atau perangkat merokok dan asap sebagai sarana untuk memenuhi kebutuhan ini.

c. Respon mengulang otomatis. Ketika seseorang telah melakukan sesuatu berkalikali dan cukup sering, maka akan tercipta pola pengulangan perilaku tertentu secara otomatis. Hal ini terutama berlaku jika 
tindakan tertentu dilakukan dalam situasi yang tidak menyenangkan, yang memberikan efek membuat seseorang merasa lebih aman dalam kehidupan sehari-hari dan rutinitas.

d.Faktor Genetik. Tidak semua orang sangat tergantung pada nikotin. Ada beberapa orang yang lebih mudah kecanduan nikotin dari pada yang lain, dengan alasan yang masih susah untuk dipahami. Dan alasan - alasan tersebut diyakini diwariskandalamkode genetik.

\section{Kesimpulan}

Merokok merupakan salah satu masalah yang sulit untuk dipecahkan. Hampir setiap remaja sampai orang tua di indonesia menghisap rokok. Padahal bahaya merokok bisa berdampak buruk bagi diri sendiri maupun orang lain. Kalau tidak di hentikan sejak dini akan berdampak buruk pada kesehatan di hari tua nanti.

\section{Daftar Pustaka}

Sodik, M. A. (2018). Merokok \& Bahayanya

Setyani, A. T., \& Sodik, M. A. (2018). Pengaruh Merokok Bagi Remaja Terhadap Perilaku dan Pergaulan Sehari-hari.

Sodik, M. A., \& Setyani, A. T. (2018). Effect of Smoking For Teens Against Behavior and Social Interaction.

Lopo, Y. M., \& Sodik, M. A. (2021). GERAKAN MASYARAKAT HIDUP SEHAT BEBAS MEROKOK.

TAHIN, M. W., \& Sodik, M. A. (2021). PENGARUH MEROKOK BAGI REMAJA TERHADAP PERILAKU DAN PERGAULAN SEHARI-HARI. 